\title{
Language - identity - culture - minority (Sociolinguistic analysis of situational use of a minority language on the example of Slovak university youth in Hungaria)
}

\author{
[Jazyk - identita - kultura - minorita (sociolingvisticka analyza \\ situacneho pouzivania minoritneho jazyka na priklade vysokoskolskej \\ slovenskej mladeze v Madarsku)]
}

\author{
Ladislav Lenovsky - Tunde Tuskova
}

DOI: 10.18355/XL.2021.14.02.17

\begin{abstract}
Language plays an important role between identity, culture and minority relations. The knowledge and use of the minority language by the elite is an authoritative attribute of language position in the whole minority. The education of elites in the Slovak minority in Hungary is determined by minority education (teaching the Slovak language, history and culture). The top of this kind of education is the university study of Slovak studies at several universities in Hungary. Graduates gain the legitimacy to become the intellectual elite of the Slovak minority in Hungary. Sociolinguistic situation analysis shows their relationship to Slovak language and real aspects of its use.
\end{abstract}

Key words: language, identity, culture, minority, university students, Slovaks, Hungary

\section{Anotácia}

Jazyk zohráva vo vzt’ahoch identity, kultúry a minority významnú funkciu. Znalost' a používanie minoritného jazyka elitou je smerodajným atribútom jeho pozície v prostredí celej minority. Výchova elít je vprostredí Slovákov v Mad’arsku determinovaná národnostným vzdelávaním (výučba slovenského jazyka, histórie a kultúry). Vrcholom vzdelávania je vysokoškolské štúdium slovakistiky na viacerých univerzitách v Mad'arsku. Absolventi získavajú legitimitu stat' sa súčastou intelektuálnej elity slovenskej menšiny v Mad’arsku. Sociolingvistická situačná analýza ukazuje, aký je ich vzt’ah k slovenčine a aspekty jej používania.

Kl’účové slová: jazyk, identita, kultúra, minorita, univerzitní študenti, Slováci, Mad'arsko

\section{Úvod}

Výskum jazyka v prostredí minorít je tradičnou a vzhl'adom na súčasné kultúrnospoločenské a politicko-ekonomické dianie $\mathrm{v}$ globálnom priestore stále aktuálnou témou nielen jazykovedy, ale aj ostatných vied o človeku, kultúre a spoločnosti. I ked' jazyk vo všeobecnosti je najsignifikantnejším etnoidentifikačným a etnointegračným faktorom, jeho pozícia v jednotlivých minoritách sa včase môže menit'. Medzigeneračná transmisia etnických znakov (vrátane jazyka) nie je automatickým ani náhodným procesom. (Murín 2016) Navyše, neprebieha len v prostredí primárnych skupín (rodiny, príbuzenstva a komunity), ale aj sekundárnych skupín (škola, lokálna societa, spoločnost'). V rámci štruktúry minority môže byt' postavenie minoritného jazyka (jeho znalost' a používanie) diferencované. Sociolingvistická analýza vnímania a používania minoritného jazyka vo vrstve budúcej intelektuálnej elity minority má vysokú výpovednú hodnotu o stave a perspektívach minority a umožňuje optimalizovat' politické, ekonomické a edukačné procesy v zmysle udržania etnokultúrnej kontinuity a identity. Elity sú vzorom a príkladom pre

XLinguae, Volume 14 Issue 2, April 2021, ISSN 1337-8384, eISSN 2453-711X 
ostatných členov minority a najviditel’nejšími reprezentantmi minority pre obklopujúci svet.

\section{Slováci v Mad’arsku}

Slováci v Mad'arsku sú tret'ou najpočetnejšou národnostnou menšinou v počte od takmer 18000 (oficiálne podl'a cenzu) po 110000 (neoficiálne, podl'a odhadu slovenských organizácií v Mad’arsku). Samozrejme, klúčová je tu otázka ich seba/definovania, ktorá je vzhl’adom na vysoký stupeň jazykovej asimilácie postavená aj na (etnickom/lokálnom) pôvode, príslušnosti (etnickej identite) a vzt’ahu k minorite (etnicite). Na území dnešného Mad’arska boli slovanskí predkovia dnešných Slovákov prítomní už pred príchodom mad’arských kmeňov v 9. storočí. Súčasní Slováci v Mad'arsku sú zväčša potomkovia Slovákov z územia dnešného Slovenska, ktorí (vtedy v rámci jedného štátu Uhorska) po ukončení osmanskej okupácie na konci 17. storočia, začali (spolu s inými prítomnými etnikami) migrovat' zo severu južným smerom do oslobodenej centrálnej a južnej časti svojej krajiny a revitalizovat' ju. Nasledovných 250 rokov sa nieslo v národno-emancipačných procesoch prítomných etník, so všetkým, čo k tomu patrí, vrátane tvrdej asimilácie, presídl'ovania, etnickej homogenizácie a najmä jazykovej asimilácie štátotvornou majoritou. Po vytvorení vlastných štátov dovtedy najväčších v Uhorsku prítomných etník sa situácia navonok upokojuje. Neustále prítomné etnické a národnostné tlenie sa pod vplyvom štátnych národných, národnostných a etnických politík, aj celoeurópskeho diania $\mathrm{v}$ druhej polovici 20. storočia formuluje cez práva menšín do legitímneho systému národnostných politických, vzdelávacích, jazykových a kultúrnych inštitúcií a organizácí. Súčasná politika kultúrnej diverzity a idea multikulturalizmu tieto pozície upevnila. Je na jednotlivých minoritách, ako vytvorený priestor na sebarealizáciu využívajú, v akej podobe a či vôbec. ${ }^{1}$

Jestvovanie (aj) slovenskej minority v Mad'arsku je determinované vlastnými politickými, ekonomickými, kultúrnymi a intelektuálnymi elitami. Ak absentujú, minorita zaniká. Súčast’ou medzigeneračného prenosu sú preto aj stratégie na udržiavanie tejto vrstvy Tento proces je neoddelitel'nou súčast'ou manažmentu minority. Realizuje sa výchovou a vzdelávaním detí a mladých príslušníkov minorít. $\mathrm{Z}$ tejto permanentne a kontinuálne vytváranej bázy l'udského potenciálu minority môže vychádzat' jej elita.

Minoritný jazyk je tu efektívnym nástrojom budovania/uvedomenia si nielen svojej identity, ale aj exkluzivity, výnimočnosti, jedinečnosti v rámci širšej spoločnosti vrátane majoritnej. Ak ovládanie minoritného jazyka prináša okrem pocitu spolupatričnosti a emocionálneho naplnenia aj možnost' sebarealizácie, špecifické pracovné príležitosti, nové sociálne kontakty a pozitívne statusy, záujem o jeho štúdium sa môže zvýšit' aj v prostredí, kde už jazyk takmer alebo úplne zanikol. Tieto otázky sú v prostredí Slovákov v Mad'arsku mimoriadne aktuálne, lebo práve jestvovanie a práca elít (ako jednotlivcov) z vel'kej miery prispeli k tomu, že Slováci ako národnostná menšina v Mad'arsku stále oficiálne jestvujú. Aká je pozícia a perspektíva slovenského jazyka v prostredí budúcich elít slovenskej menšiny v Mad'arsku dnes?

\section{Sociolingvistický výskum slovenského jazyka v Mad'arsku}

Problematika používania slovenského jazyka nastupujúcou generáciou slovenskej inteligencie v Mad'arsku doposial' nebola podrobnejšie skúmaná. Doterajšie početné

\footnotetext{
${ }^{1} \mathrm{~K}$ problematike hodnotových orientácií v súčasnej globalizovanej spoločnosti bližšie Danek, 2019, s akcentom na aktuálne edukologické trendy v rámci národnostného vzdelávania a výučby cudzích jazykov vakademickom prostredí bližšie napríklad Ivanishcheva 2016, Sirotová Michvocíková, 2016 a 2019 alebo Lalinská - Stranovská - Gadušová, 2020.
} 
sociolingvistické výskumy boli zamerané na Slovákov v Mad’arsku celkovo, alebo na prostredie slovenskej mládeže v Mad'arsku všeobecne. ${ }^{2}$

Systematický, pravidelný sociolingvistický výskum slovenčiny začína až v 80. rokoch 20. storočia. (Ondrejovič, 2008: 98-116) Dovtedajší záujem predstavujú predovšetkým dialektologické výskumy. Pohl'ad jazykovedného výskumu sa obrátil od jazykového systému k fungovania tohto systému v komunikácii. Sociolingvistika sa tak ako hraničná disciplína zameriava viac na výskum jazyka $\mathrm{v}$ spätosti so spoločnost'ou, v ktorej daný jazyk funguje. (Buzássyová, 1989: 111) Podl’a Dolníka, „kým systémové normy zahíňajú jazykové prostriedky a pravidlá, ktoré jazykové spoločenstvo prisudzuje jazykovým útvarom ako im vlastné, komunikačné normy sa vytvárajú konvencionalizáciou jazykových (aj mimojazykových) prostriedkov v istých komunikačných podmienkach. V súvislosti s týmito podmienkami sa pozornost' upriamila na komunikačné sféry.... Ukazuje sa, že kým z funkčného stanoviska je základovým útvarom nespisovná varieta a nadstavbovou formou spisovný jazyk, zo štruktúrneho zorného uhla je to naopak.“ (2010: 23) Bosák dodáva, že ,,jazyk je nielen teoretický konštrukt, ale aj reálny komunikačný systém, ktorý funguje v konkrétnych (národných, etnických) podmienkach, nie iba $\mathrm{v}$ explicitnom, vybranom úze ovplyvňovanom len ,dobrými autormi‘.“ (1995: 19) Problematiku slovenskomad’arských kontaktových javov sociolingvisticky spracovali Lanstyák (1996, 2002, 2005), Lanstyák - Szabómihály (1997) a Štefánik (2004a, 2004b).

Sociolingvistické výskumy špeciálne orientované na Slovákov v Mad’arsku začínajú v 90. rokoch 20. storočia. Zázemím, o ktoré sa mohli opierat' boli predovšetkým výskumy dialektologického charakteru realizované od 50. rokov 20. storočia. ${ }^{3}$ Zásadnou prácou je dvojjazyčná publikácia Atlas slovenských nárečí v Mad’arsku (Fügedi - Gregor - Király, 1993).

Problematiku súčasného slovenského jazyka v Mad’arsku a dvojjazyčnej kultúry v interdisciplinárnych súvislostiach predstavujú kl'účové práce Divičanovej (1999c, 2001b, 2002a, 2004) a Žilákovej (2004a, 2004b, 2005, 2008c). Autorky tu spracúvajú témy ako etnokultúrne zmeny na slovenských jazykových ostrovoch v Mad’arsku, zmeny v hierarchii hodnôt materinského jazyka, ambivalentnost' významu jazyka, jazyková a obsahová dualita kultúrnych modelov, funkčné vrstvy a vývin slovenčiny a jej jazykový obraz sveta (the linguistic image of the world), bilingvizmus ako fenomén Slovákov v Mad'arsku.

Následné výskumy sa zaoberajú predovšetkým synchrónnym stavom nárečovej podoby slovenského jazyka používanej v rôznych lokalitách Mad’arska obývaných Slovákmi, bilingvizmom, jazykovým obrazom sveta Slovákov v Mad’arsku (Hornokné Uhrin, 2000; Tuska, 2002; Lesfalviné Csengődi, 2010; Császári, 2011; Szabóné Marlok, 2012; Szabóová, 2012).

V kontexte prítomného príspevku sú dôležité výsledky Homišinovej sociologického výskumu stavu etnickej identity, ktorý sa orientoval práve na inteligenciu slovenskej minority žijúcej v Mad'arsku. Homišinová (2003: 16) výber skúmanej vzorky argumentuje tým, že vlastná inteligencia (ako spoločenská kategória) najviac zabezpečuje kohéziu minority. „Rozvoj etnickej identity musí byt' podmienený predovšetkým etnouvedomovacími aktivitami, ktoré vychádzajú zvnútra samotnej slovenskej menšiny, t. j. ich záujmom o zachovanie svojej etnickej identity.“ (Homišinová, 2003: 14). Konštatuje, že napriek výraznému vplyvu mad’arskej spoločnosti sú vedomie spolupatričnosti a silná väzba k slovenskému etniku v kruhu

\footnotetext{
${ }^{2}$ Výnimkou sú výskumy slovenských vysokoškolákov z Mad’arska študujúcich na slovenských univerzitách, bližšie napr. Lenovský 2008, alebo Hornok 2020.

${ }^{3}$ Ide o práce Štolc, 1949; Blanár, 1950; Ondrus, 1956; Fügedi - Gregor - Király, 1993, neskôr Gregor, 1998; Žiláková/Zsilák, 1986, 1991, 1992, 1993, 1996, 2008a, 2008b; Divičanová, 1999a, 1999b; Balleková, 2004, 2006; Tušková, 2001, 2005, 2007-2008.
}

XLinguae, Volume 14 Issue 2, April 2021, ISSN 1337-8384, eISSN 2453-711X 
slovenskej inteligencie v Mad'arsku stále zachované. (Homišinová, 2003: 246) Odhalenie mechanizmov zachovávania a reprodukcie etnickej identity v rodinnom prostredí potvrdzuje, že na asimiláciu menšín vplývajú hlavne jazykové faktory a vnímanie vlastnej etnickej identity. (Homišinová, 2006: 14)

Doterajšie empirické výskumy potvrdili: 1. aktívne používanie slovenského jazyka v príslušných lokalitách a situáciách, 2. pozíciu slovenčiny ako druhotného jazyka, 3. pozíciu mad’arčiny ako jazyka dominantného. Vo všetkých vrstvách kultúry sa používa ústna i písomná podoba slovenského jazyka, hoci značné rozdiely sú v miere, aj v kvalite jazykovej praxe jednotlivých lokalít. (Uhrinová, 2008: 141)

Paralelne s výskumom týkajúcim sa používania slovenského jazyka sa sleduje aj problematika dvojjazyčnosti, napr. Szabóová, 2004: 392-407, Telekešová-Vámošová, 2004: 334 - 344, Štefánik, 2004a: 325 - 333. Výskum sa zameriava na jazykovú úroveň bilingválnych študentov vysokých škôl alebo žiakov základných a stredných škôl (mad'arsko-slovenskú dvojjazyčnost', dvojitú identitu). Pri vytváraní a udržiavaní dvojjazyčnosti (v prípade jednotlivca aj komunity) zohráva kl’účovú úlohu motivácia. Subjekt si osvojuje obidva, prípadne i viac jazykov na takej úrovni, ktorá je dostatočná pre komunikačné potreby. (Štefánik, 2004a: 330-331) Vo výskumoch sa slovenská mládež komplexne analyzuje objekt výskumu, zist’uje sa jej jazykovokomunikačné správanie, stratégie situačného „prepínania kódov“, etnické parametre, variety používaných jazykov aj širšie, sociálne, kultúrne, či náboženské súvislosti. Najnovšou metódou v rámci uvedených výskumov je jazyková autobiografia, ktorá umožňuje uchopit' osobnostnú úroveň prežívanej identity v kontexte minoritných spoločenstiev. (Uhrinová 2015: 248-274)

\section{Ciel' a metodika výskumu}

Ciel'om výskumu je zistit', ktorý z jazykov používajú mladí l'udia slovenskej národnosti alebo pôvodu v Mad'arsku v ktorých komunikačných sférach a situáciách, aký majú postoj a vzt’ah k menšinovému jazyku, jazyku svojich predkov. Aké sú ich názory na výmenu jazyka (oslabenie dominantného postavenia slovenčiny ako minoritného jazyka). Predmetná štúdia prináša interpretáciu sociolingvistických a etnolingvistických výsledkov samostatného výskumu, ktorý bol inšpirovaný širšie koncipovaným celoštátnym výskumom jazykovej inakosti vkontexte možností zachovania jazykov menšín v Mad'arsku. ${ }^{4}$ Dôvodom prítomného výskumu bola snaha doplnit' vekovú kategóriu 20-40 ročných v rámci celoštátneho výskumu a rozšírit' ju o vysokoškolákov. Navyše, výsledky sa týkajú budúcej slovenskej inteligencie v Mad'arsku a môžu byt' iné ako v už realizovanej trojpásmovej vekovej škále. Otázky dotazníka boli formulované $\mathrm{v}$ slovenčine, niektoré pojmy bolo potrebné študentom preložit', respektíve vysvetlit'.

\section{Výskumná vzorka}

Výskumná vzorka je budúca slovenská inteligencia v Mad’arsku, ktorá ako sociálna skupina bude zohrávat' klúčovú úlohu v národnostvom jestvovaní Slovákov v Mad'arsku a ich etnoidentifikačných a etnokultúrnych procesoch. Ide o poslucháčov

\footnotetext{
4 Celoštátny projekt Dimenzie jazykovej inakosti: možnosti zachovania jazykov menšín (NKFPč.5/126/2001) bol realizovaný podla koncepcie Oddelenia súčasných jazykov Jazykovedného ústavu Mad’arskej akadmie vied a Katedry súčasného mad’arského jazyka univerzity Eötvösa Loránda. Výskum sa zameriaval na šest' dvojjazyčných národnostných komunít v Mad’arsku (Slováci, Nemci, Rumuni, Chorváti, Srbi, Rómovia). Podmienkou bolo, aby výskumníci komunitu poznali, najlepšie aby z nej pochádzali, ovládali jazyk, resp. použivanú varietu, aby práca $\mathrm{s}$ respondentmi prebiehala $\mathrm{v}$ menšinovom jazyku. Skúmanou lokalitou slovenskej menšiny bol Slovenský Komlóš (Tótkomlós). Sociolingvistický dotazník pozostával zo 142 otázok v slovenskom jazyku. 70 respondentov bolo $\mathrm{v}$ troch vekových kategóriách: I. 20 - 40 rokov; II. 41 - 60 rokov; III. 61 - 80 rokov.
} 
slovakistiky v Mad'arsku ${ }^{5}$ vo veku 19 - 29 rokov. Podmienkou výberu bolo mad’arské štátne občianstvo a slovenský pôvod. V čase výskumu uvedenej podmienke vyhovovalo 30 respondentov. ${ }^{6} 83 \%$ (25 študentov) tvoria ženy a $17 \%$ (5 študentov) muži. $20 \%$ (6) uviedlo slovenskú národnost', $23 \%$ (7) slovenskú a mad'arskú národnost' (dekladovali dvojitú identitu), 57 \% (17) uviedlo mad’arskú národnost'. Výskum nelokalizoval respondentov podl'a bydliska, ale školy.

$33 \%$ (10) študovalo pred vysokoškolským štúdiom 12 rokov v národnostnej škole (8 rokov na slovenskej základnej škole a 4 roky na slovenskom gymnáziu), 27 \% (8) navštevovalo len slovenskú základnú školu a nepokračovalo v štúdiu na slovenských gymnáziách a 40 \% (12) na otázku dovtedajšieho národnostného vzdelávania neodpovedalo. Polovica respondentov (15) sa naučila po slovensky v škole, resp. škôlke, 30 \% (9) doma v rodine, 3 \% (1) paralelne doma a v škole, resp. škôlke. 3 poslucháči $(10 \%)$ sa naučili po slovensky až v neskoršom období a dvaja (7 \%) sa slovenský jazyk nenaučili. Okrem jedného si každý osvojil mad’arčinu doma, v rodinnom prostredí.

Náboženská štruktúra vzorky je $43 \%$ (13) katolíkov a $47 \%$ (14) evanjelikov a. v., 10 \% (3) neuviedlo žiadne vierovyznanie. 50 \% (15 osôb) navštevuje bohoslužby len počas väčších sviatkov (približne štyrikrát ročne), 9 (30\%) nenavštevuje vôbec, 5 (17 \%) raz mesačne a $1(3 \%)$ raz týždenne. $16(54 \%)$ navštevuje bohoslužby v mad'arčine, 7 (23 \%) v mad'arčine aj v slovenčine, 7 (23\%) neodpovedalo.

Vo výskumnej vzorke sú prevažne ženy, ktoré študujú slovenčinu ako samostatný odbor. Možno konštatovat', že tá polovica respondentov, ktorá pred vysokoškolským štúdiom 8 alebo 12 rokov študovala $\mathrm{v}$ národnostných školách, je tá polovica študentov, ktorá sa slovenčinu naučila $\mathrm{v}$ škole alebo $\mathrm{v}$ škôlke. K neskorším úvahám je dôležité zistenie, že všetci okrem jedného si osvojili mad'arský jazyk už doma. Z hl'adiska vierovyznania je pomer študentov vyrovnaný.

Doterajšie poznanie problematiky umožňuje stanovenie hypotéz, že:

1. V súčasnosti sú všetci príslušníci slovenskej národnosti v Mad’arsku, ktorí ovládajú slovenčinu, slovensko-mad’arskými bilingvistami, pričom v prípade detí a mládeže je mad’arčina dominantným jazykom, slovenský jazyk plní etnosignifikatívnu úlohu.

2. Skúmaná generácia je plne integrovaná do majority a jazykovo asimilovaná v takej miere, že k medzigeneračnej transmisii minoritnej identity slovenský jazyk už neslúži. Je to viac ,jazyk predkov“ ako praktický nástroj použitel'ný v reálnom každodennom živote. Slovenský jazyk je tu exkluzívnou záležitost'ou predovšetkým osobnej vol’by alebo/aj profesionálneho záujmu.

\section{Etnická autoidentifikácia}

Pri požiadavke deklarovania národnosti 17 (takmer 60\%) študentov uviedlo mad'arskú národnost', 6 (20\%) respondentov slovenskú a v približne rovnakom zastúpení (7) deklarovalo dvojitú - slovenskú i mad’arskú národnost'. Zaujímavá zmena etnickej identifikácie sa objavuje pri jasnej otázke, či sa považujú za Slovákov. Zastúpenie tých, ktorí deklarovali mad'arskú národnost' je takmer nezmenené (16), no počet tých, ktorí predtým deklarovali slovenskú národnost' klesol na 2 (7\%) a tých, ktorí uviedli dvojitú národnost', stúpol na 12 (40\%). Ide tu o špecifickú kvalitu identity definovanú pocitom dvojitej väzby.

\footnotetext{
${ }^{5}$ Katedra slovenského jazyka a literatúry PF Gyulu Juhásza Segedínskej univerzity, PF pre učitel'ky materských škôl VŠ Samuela Tessedika v Sarvaši, Katedra slovenského jazyka a literatúry PF Jánosa Vitéza v Ostrihome, Katedra slovakistiky na Univerzite Eötvösa Loránda v Budapešti.

${ }^{6} \mathrm{Na}$ uvedených katedrách $\mathrm{v}$ čase výskumu študovali aj slovenskí občania so slovenskou, alebo mad’arskou národnost'ou a mad'arskí občania $\mathrm{s}$ mad’arskou národnost'ou, ktorých $\mathrm{k}$ štúdiu slovakistiky viedol osobný záujem. Títo neboli objektom výskumu.
}

XLinguae, Volume 14 Issue 2, April 2021, ISSN 1337-8384, eISSN 2453-711X 
Tí, ktorí sa považujú za Slovákov, to zdôvodnili výberom odpovede , lebo hovorím po slovensky" (v zmysle, že slovenčinu ovládajú). Šiesti uviedli, že kvôli rodičom, resp. starým rodičom (slovenského pôvodu). Polovica z tých, ktorí uviedli dvojitú identitu, odpovedala: „,lebo patrím do tohto kolektívu“. (!) Vplyv minoritného jazyka na minoritnú identifikáciu v skúmanom prostredí objasňuje odpoved' na otázku: Aký je váš materinský jazyk? Takmer všetci respondenti (93\%) uviedli mad'arčinu, jeden slovenčinu a jeden obidva jazyky. Je evidentné, že okrem niekol'kých prípadov minoritnú identitu skúmaná skupina definuje nie jazykom, ale pôvodom, impulzom z prostredia rodiny, alebo sociálno-psychologickým faktorom - minoritným kolektívom.

$\mathrm{Z}$ výpovedí respondentov možno uviest' konštatovanie:

„Slováci žijú na Slovensku. My žijeme tu v Mad'arsku. Ale my sme ini, ako Mad'ari. Tí, čo nemajú Slovákov predkov, ani nie sú zo slovenských dedín, ako my. A prečo by som sa neučil po slovensky, ked' aj ja patrím k nim. Mám slovenskú národnost'. "

Dôvodom tohto čiastkového výsledku je etablované slovenské národnostné školstvo v Mad'arsku. Sledovaní respondenti predtým 8 či 12 rokov študovali v slovenských školách, kde sa (nielen) na vyučovaní oboznámili so slovenskou kultúrou, históriou, literatúrou (vrátane národnostnej) a stali sa súčast'ou takéhoto „exkluzívneho“ kolektívu. Z neformálnych rozhovorov so študentmi vyplynulo, že so slovenským jazykom majú svoje zámery, predpokladajú, že jeho ovládanie im pomôže nájst' si lepšie pracovné príležitosti.

Výsledky predmetného výskumu sa v tomto výrazne líšia od výsledkov výskumu realizovaného $\mathrm{v}$ mimouniverzitnom prostredí, kde je význam etnoidentifikačných faktorov usporiadaný inak, v poradí: slovenčina ako materinský jazyk, rodičia, kolektív, používanie slovenčiny. ${ }^{7}$ Analýza empirických údajov celkovo poukazuje na vel'ký rozdiel medzi generáciami (ovládanie menšinového jazyka je v prípade staršej generácie lepšie a používanie častejšie, lebo miestom je domáca lokalita). V prípade mladšej generácie ide o kapitál na vlastné uplatnenie sa v praxi. V prípade staršej generácie ide o tzv. integrálny motív (včlenenie chápané ako prirodzené), zatial' čo u vysokoškolských poslucháčov je to inštrumentálny motív (nástroj). (TelekešováVámošová, 2004: 339) Priebežné výsledky poukazujú na význam národnostného školstva, ktoré je prostredím vytvárania minoritných kolektívov, inklúzie do národnostného života, budovania predpokladov, získavania schopností, zručností a vytvárania nástrojov na neskoršiu aktívnu participáciu v spolkovej činnosti menšiny. Vzt’ah niektorých Slovákov žijúcich v Mad'arsku k slovenčine deklarujú nasledujúce výroky ${ }^{8}$ :

„Najradšej mám obidva jazyky. Cítim sa dvojkultúrna, dvojjazyková. Slovenčina zohráva v mojom živote dôležitú úlohu, predovšetkým pracovnú, lebo pracujem s ňou každý deñ “

„Slovenčine môžem d'akovat' velice moc, jazyk, taniec. Ked'vystupuje človek a čuje tlesk, to je taký cit, že v živote nezabúda. "

„Hlavné miesto má slovenčina v mojom živote. Aj ked' počitam, ja neviem že egy-ketto” alebo ezer po mad'arsky. Ja všetko po slovensky. Napriklad bola som v nemocnici, aj vtedy, ked' ma uspávali som sa rozprávala. Opýtali sa ma, že milyen nyelven beszélt? Hovorím im, že biztos szlovákul. “ (Tušková - Uhrinová, 2018)

\footnotetext{
${ }^{7}$ Napríklad pri spomínanom výskume v Slovenskom Komlóši sa za Slovákov považovalo podla slovenčiny ako materinského jazyka 37,7 \% (23 respondentov), podl'a rodičov 29,5\% (18), kolektívu 24,6 \% (17), používania slovenčiny 8,2 \% (5). (Tóth - Tušková - Uhrinová - Žiláková, 2005: 284-286)

${ }^{8} \mathrm{Z}$ výskumu v slovenskej lokalite Tardoš bližšie Tušková - Uhrinová 2018.
} 


\section{Situačné používanie minoritného jazyka}

$\mathrm{Na}$ základe doterajších poznatkov bolo možné predpokladat', že z hl'adiska etnogenézy Slovákov v Mad’arsku bude skúmané prostredie dôkazom transformácie materinského aj komunikačného jazyka $\mathrm{z}$ pôvodne dominantnej slovenčiny na dominantnú mad’arčinu. Prekvapujúca však bola vysoká dominancia mad’arčiny (93\%). ${ }^{9}$ Sledovaní respondenti si mad'arčinu osvojili v ranom detstve. Naučili sa ju ako prvý jazyk. Preto väčšina $\mathrm{z}$ nich vníma $\mathrm{v}$ kontexte národnosti ako prvoradé kritérium nie jazyk, ale pôvod. V otázke definovania materinského jazyka je v skúmanom prostredí dôležitá aj kompetencia - ktorý jazyk ovláda lepšie. Dobre to vykresl'uje vyjadrenie jedného študenta: „Ja by som rád povedal, že mojím materinským jazykom je slovenčina, ale hned' po prvej vete by zbadali, že to tak nie je. Neviem tak dobre po slovensky. " Vyjadrenie poukazuje aj silu emocionálnej väzby na jazyk predkov ako faktor pri rozhodovaní. Táto väzba je charakteristická najmä pre staršiu a strednú generáciu, u mladých (vrátane skúmanej vzorky) okrem malého počtu výnimiek už nie je prítomná. Vo všeobecnosti, v súčasnosti okrem vyučovacích hodín slovenčiny študenti nie sú v kontakte so slovenským jazykom. Jazykový kontakt so živým slovenským jazykom a prostredím im v snahe o zdokonal'ovanie sa $\mathrm{v}$ ňom chýba.

\section{Ovládanie minoritného jazyka}

Otázka ovládania minoritného jazyka (kvalitatívna úroveň) je v kontexte jeho používania v situáciách kedy môže byt' použitý, kl'účová. V situácii, kedy je možné hovorit' mad'arsky alebo slovensky, tí, ktorí ho neovládajú na potrebnej úrovni (alebo si to myslia), sa hanbia a vyberajú si radšej mad'arčinu, ktorej používanie je v prostredí Slovákov v Mad'arsku považované za štandard.

Čast' dotazníka sa týkala sebahodnotenia miery ovládania jazyka/jazykov. Merítkom boli L'udové noviny - najpopulárnejšie a najčítanejšie slovenské periodikum v Mad'arsku. Referenčná 5 stupňová škála ukazuje, že $47 \%$ (14) rozumie textu týchto novín l'ahko, viac-menej im rozumie $23 \%$ (7), tažko im rozumie $10 \%$ (3) a $10 \%$ (3) rozumie dokonale. Odpoved' vôbec nerozumiem si nevybral nikto. $10 \%$ (3) neodpovedali.

Horšia zrozumitel'nost' slovenského textu v prípade novín súvisí s tým, že medzi jazykom slovenskej tlače v Mad'arsku a jazykovými znalost’ami čitatel'ov (vrátane respondentov) je nezhoda. Absencia živého jazykového prostredia spôsobuje, že jazykové prostriedky využívané v publicistickom štýle (napr. vel'ká miera synonymie, množstvo nových, cudzích a štylisticky príznakových slov, odborných termínov, žurnalizmov a frazeologizmov) sú pre nich len viac-menej zrozumitel'né. V prípade mad'arského textu všetkému dokonale rozumie $100 \%$ respondentov.

Sebahodnotenie úrovne používania nárečovej formy ${ }^{10}$ slovenského jazyka prináša nasledovné zistenia. Spomedzi opýtaných nikto $(0 \%)$ nerozpráva nárečím dokonale, l'ahko ho používajú šiesti (20\%), viac-menej dobre deviati (30\%), t’ažko ním komunikujú šiesti $(20 \%)$ a šiesti $(20 \%)$ vôbec neovládajú nárečie svojich predkov. Traja (10\%) neodpovedali.

Sebahodnotenie úrovne ovládania spisovnej slovenčiny potvrdzuje, že nikto $(0 \%)$ ju dokonale neovláda. $53 \%$ (16) deklaruje, že ju ovláda viac-menej dobre, l'ahko ňou rozpráva $30 \%$ (9), skôr t’ažko $10 \%$ (3) a vôbec ju neovláda 7 \% (2). Spisovnú

\footnotetext{
9 Spomínaný výskum v Slovenskom Komlóši uvádza 68 \%-né zastúpenie respondentov udávajúcich za svoj materinský jazyk slovenčinu, $19 \%$ deklarovalo dva materinské jazyky, mad'arčinu považovalo za svoj materinský jazyk $13 \%$ respondentov.

${ }^{10}$ Pod nárečovou formou sa rozumie nárečová podoba slovenčiny v obci, odkial' respondent pochádza.
}

XLinguae, Volume 14 Issue 2, April 2021, ISSN 1337-8384, eISSN 2453-711X 
mad’arčinu ovláda dokonale 97 \% (29) a 1 osoba (3\%) sa vyjadrila, že v tomto jazyku rozpráva l'ahko.

Skutočnost', že skúmaná skupina ovláda spisovnú slovenčinu lepšie ako slovenské nárečie domovskej lokality vysvetl'uje fakt, že ide o generáciu, ktorá sa narodila v 80. rokoch 20. storočia, ked' slovenčina ako materinský jazyk už bola mimoriadne ojedinelá. Navyše, aj v školskej výučbe bol neprimeraný (čiastočne negatívny) prístup $\mathrm{k}$ miestnym dialektom, následkom ktorého rodičia prestali komunikovat' so svojimi det'mi po slovensky. (Žiláková, 2004b)

Vyššia úroveň znalosti spisovného slovenského jazyka v porovnaní s jeho nárečovou podobou je výsledkom vzdelania (vyučovacím jazykom na slovakistických katedrách v Mad’arsku je spisovná slovenčina). Je zaujímavé, že medzi respondentmi sa ešte nájdu aj takí, ktorí dokážu komunikovat' v nárečovej podobe jazyka (viac-menej - 30 $\%$, l'ahko-20\%).

Za bližší jazyk považuje 57 \% (17) mad'arčinu, obidva jazyky sú rovnako blízke pre $33 \%$ respondentov (10) a pre jedného (3\%) je to slovenčina. $7 \%$ (2) neodpovedalo. $87 \%$ (26) používa častejšie mad'arčinu, obidva jazyky rovnako často používa $13 \%$ (4) a nikto (0 \%) si nevybral možnost' používania slovenčiny častejšie ako mad'arčiny. Jeden (3 \%) číta viac v slovenčine a ostatní (94 \%/ 28) viac v mad’arčine. Jeden (3\%) neodpovedal. Nikto si nevybral možnost', že by čítal v rovnakom zastúpení oboch jazykov.

Respondenti (na základe sebahodnotenia) najčastejšie používajú mad'arčinu (86 \%/ 25 ) a skoro všetci čítajú viac v mad’arčine (94 \%( 28). Pozoruhodné je, že $33 \%$ (10) označilo obidva jazyky ako rovnako blízke, čiže deklarovalo dvojitú väzbu, a to i napriek nezanedbatel'nej komunikačnej bariére a viac pasívneho používania slovenského jazyka.

\section{Používanie minoritného jazyka v prostredí primárnych skupín}

Z výsledkov výskumu vyplýva, že z respondentov má 13 (43\%) aspoň jedného rodiča a dvoch starých rodičov Slovákov, 10 (33\%) má Slovákov obidvoch rodičov a štyroch starých rodičov a 7 (26\%) nemá ani rodičov, ani starých rodičov Slovákov.

Z frekvenčnej analýzy odpovedí na otázky týkajúce sa situačného výberu jazyka vyplynulo, že $60 \%$ (18) hovorí s matkou vždy po mad'arsky, $20 \%$ (6) obyčajne po mad’arsky, obidva jazyky používa $17 \%$ (5) a iba jeden (3\%) sa so svojou matkou obyčajne rozpráva po slovensky. S matkou sa vždy po slovensky nerozpráva nikto. Približne rovnaké výsledky sú v súvislosti s komunikáciou s otcom: 67 \% (20) vždy po mad'arsky, $10 \%$ (3) obyčajne po mad'arsky, obidva jazyky používa $20 \%$ (6). Obyčajne, alebo vždy po slovensky sa s otcom nerozpráva nikto.

Analýza odpovedí na rovnakú otázku, ale so starými rodičmi z matkinej a z otcovej strany je prekvapujúca. Ked’že v prostredí tejto generácie sa ešte nezriedka používa slovenčina, posun škály jej používania pri komunikácii s vnúčatami smerom k výraznejšiemu používaniu vôbec nebadat. ${ }^{11}$ Nikto z respondentov sa nerozpráva so svojimi starými rodičmi výlučne po slovensky, 10 \% (3) používa obyčajne slovenčinu v komunikácii so starými rodičmi z matkinej strany, ale so starými rodičmi z otcovej strany nikto. Používanie slovenského aj mad’arského jazyka v rovnakej miere v komunikácii so starými rodičmi z matkinej strany deklaruje $40 \%$ (12) respondentov, so starými rodičmi z otcovej strany len $17 \%$ (5). Obyčajne mad'arčinu v komunikácii so starými rodičmi z matkinej strany používa $10 \%$ (3), so starými rodičmi z otcovej strany $7 \%$ (2). Výlučne mad’arčinu v komunikácii so starými rodičmi z matkinej strany používa $40 \%$ (12), z otcovej strany $70 \%$ (21). V prípade komunikácie so súrodencami $57 \%$ (17) používa výlučne mad'arčinu, 17 \% (5) obyčajne mad'arčinu,

\footnotetext{
${ }^{11}$ O používaní slovenského jazyka v prípade staršej generácie bližšie Tóth - Tušková - Uhrinová - Žiláková, 2005.
} 
$17 \%$ (5) rovnako často oba jazyky. Obyčajne alebo výhradne slovenčinu nikto. Traja nemajú súrodenca.

$\mathrm{Z}$ výpovedí respondentov:

„Slovensky som sa naučila až v škole. Doma so mnou nikto nehovoril po slovensky. Nemám problém hovorit, alebo rozumiet. Nehovorím na sto percent, ale všetko rozumiem, aj viem povedat'. "

„Po slovensky doma so starkou. Ale nebolo to preto, že je to po slovensky, ale preto, že tu u nás stari l’udia aj tak sa zhovárajú. A ja som sa to naučila. Nárečie. Potom $v$ škole lepšie, spisovne. Ale to je t’ažké. "

„So súrodencami stále hovorím po mad'arsky, ani by ma nenapadlo s nimi po slovensky hovorit'. Tak sme zvyknutí a väčšinou sa pohybujeme v mad'arskom prostredí. Je to aj l’ahšie pre nás. “

Možno konštatovat', že respondenti len po slovensky nekomunikujú so žiadnymi rodinnými príslušníkmi, obyčajne so svojou matkou sa po slovensky rozpráva len jeden, traja so starými rodičmi z matkinej strany. Najčastejšie voleným variantom bola odpoved' vždy po mad'arsky (so starými rodičmi z matkinej $40 \%$; so starými rodičmi z otcovej strany $70 \%$; s otcom $67 \%$; s matkou $60 \%$; so súrodencami $57 \%$ ). Alebo naopak, len po mad'arsky najmenej komunikujú so starými rodičmi z matkinej strany. Najväčšia čast' študentov s nimi komunikuje dvojjazyčne (40 \%/ 12). Oboma jazykmi komunikujú s ostatnými príslušníkmi rodiny skoro o polovicu menej ako so starými rodičmi z matkinej strany. $\mathrm{V}$ rodinnom prostredí respondentov sa preferuje komunikácia v mad'arskom jazyku. Tento jazykový stav medzi generáciami ovplyvní aj budúce jazykové preferencie $\mathrm{v}$ daných komunikačných sférach a komunikačných situáciách.

Používanie slovenského jazyka v rodinnom kruhu nie je bežné. Vysvetlenie sa ukrýva $\mathrm{v}$ jazykových preferenciách respondentov (ako subjektívneho parametra) aj prostredia v ktorom žijú (ako objektívneho parametra).

V prípade skúmanej skupiny možno predpokladat', že vo všetkých komunikačných situáciách dominuje mad’arský jazyk. Výber a používanie minoritného jazyka je v prostredí etnickej minority mimoriadne dôležitým aspektom, lebo jazyk nie je len prostriedkom na sformulovanie a vyjadrovanie myšlienok, ale aj symbolom tých, ktorí ho použivajú. (Skutnabb-Kangas, 1991: 364). Samotné používanie minoritného jazyka (bez ohl'adu na to, či ako materského) je dôležitým etnointegrujúcim a etnoidentifikačným nástrojom.

\section{Používanie minoritného jazyka v prostredí sekundárnych skupín}

Traja $(10 \%)$ respondenti počas štúdia pri komunikácii s učitel’om slovenčiny používajú výlučne slovenský jazyk. $17 \%$ (5) použiva obyčajne slovenčinu, výlučne mad'arčinu $7 \%$ (2), občas mad'arčinu $13 \%$ (4). Najväčšia čast' (53\%/ 16) používa oba jazyky.

„Aj ja som sa naučila po slovensky až v škole. Ale poznala som to z domu. V škole nás dobre naučili. A boli aj takí, čo vôbec nevedeli a teraz dobre vedia. "(respondentka)

Nielen vzt’ah slovenčiny a náboženstva, ale aj religiozitu študentov ${ }^{12}$ deklaruje fakt, že viac ako polovica respondentov $(54 \%$ /16) sa nevyjadrila, lebo bohoslužby v kostole nenavštevuje a nemá žiadny vzt’ah s kňazom, ani kontakt s cirkvou. Z tých, ktorí sa bohoslužieb zúčastňujú, väčšina komunikuje s kňazom vždy po mad'arsky (43 \%/ 13) a s ostatnými členmi cirkevného zboru vždy po mad’arsky 40 \% (12 osôb). Nikto nekomunikuje s kňazom ani s členmi cirkevného zboru obyčajne po mad'arsky, ani výlučne po slovensky. Len jeden používa obidva jazyky a jeden s členmi

${ }^{12}$ Vzt’ah jazyka a religiozity môže byt' v niektorých prípadoch (najmä v minoritnom prostredí) mimoriadne intenzívny (napr. podla Borys - Garmash 2019) a preto bolo nevyhnutné preskúmat' jeho relevanciu.

XLinguae, Volume 14 Issue 2, April 2021, ISSN 1337-8384, eISSN 2453-711X 
cirkevného zboru komunikuje obyčajne po slovensky. Je evidentné, že náboženstvo ani cirkev už nemá takmer žiadny vplyv na používanie slovenského jazyka mladými príslušníkmi slovenských komunít v Mad'arsku. Iniciatíva Celoštátnej slovenskej samosprávy na znovuoživenie cirkevných obradov v slovenskom jazyku zatial' v prostredí mládeže nerezonuje. (Uhrinová, 2011b: 87, Nobiková, 2011: 259)

„U nás do kostola ked’ je omša, tak v mad'arčine. A ked' je párkrát do roka aj po slovensky, tak len zopár starých žien tam príde. Tie sa ešte modlia po slovensky, aj tie pesničky kostolné slovenské poznajú. Nám je lepšie po mad'arsky. “(respondentka)

V komunikácii so susedmi $44 \%$ (13) používa vždy mad'arčinu, 40 \% (12) nevybralo žiadnu odpoved', lebo nemá susedov slovenského pôvodu. Nikto z respondentov nepoužíva výlučne slovenčinu, jeden používa obyčajne slovenčinu a štyria (13\%) používajú oba jazyky.

„Na ulici doma ked' sa mi prihovori niekto po slovensky, alebo pozdraví, tak slovensky mu odpoviem. Lebo ma pozná, že viem. Inak nie. " (respondent)

V prípade komunikácie s priatel'mi a známymi (Slovákmi) je výber jazyka ovplyvnený aj prítomnost' Mad'ara. Najviac respondentov (33\%/10) používa oba jazyky (komunikuje dvojjazyčne) so svojimi priatel'mi Slovákmi a ak je prítomný aj Mad'ar, dvojjazyčnost' sa zvýši na 47 \% (14). Dvaja respondenti (7 \%) používajú v rozhovoroch s priatel'mi vždy slovenčinu, ale ak je prítomný Mad'ar, používajú vždy mad'arčinu. Obyčajne slovenčinu používa $23 \%$ (7), ale v prítomnosti Mad'ara sa podiel zníži na $10 \%$ (3). Obyčajne mad’arčinu používa $10 \%$ (3) bez ohl'adu na prítomnost' Mad'ara. $7 \%$ (2) sa rozprávajú so svojimi priatel'mi Slovákmi vždy po mad'arsky a 30\% (9 osôb) vždy po mad'arsky ked' je prítomný aj Mad'ar. (Prechod na mad’arčinu v prípade prítomnosti mad'arského kamaráta je prejavom slušnosti a nevzt'ahuje sa len na skúmanú skupinu.)

„,Ked' je akcia slovenská, festival, alebo prídu zo Slovenska, tak vtedy. “ (respondent)

„,Tí, čo sú v spevokole, alebo v súbore, tí aj na Slovensko chodia. Tí viac vedia, alebo sa môžu zhovárat' po slovensky. " (respondentka)

Oblast' komunitného života v kontexte používania slovenčiny zachytávajú vybrané komunikačné situácie. Samozrejme, dôležitým aspektom je konkrétny charakter domácej lokality respondenta. Jazyk v komunikácii na obecnom/mestskom úrade doma: výlučne mad'arčinu používa $43 \%$ (13), 20\% (6) preto, lebo u nich na úrade nepracujú slovensky hovoriaci pracovníci. Oba jazyky používa 14 \% (4 osoby), obyčajne slovenský $17 \%$ (5), vždy slovenský $3 \%$ (1), rovnako jeden použiva obyčajne mad'arský jazyk.

Pri otázke používania jazyka v obchode $40 \%$ (12) uviedlo, že u nich v obci/meste predavači v obchode nevedia po slovensky. Prekvapilo však dost' vysoké percento respondentov (20 \%/ 6) ktoré v obchode používa vždy slovenčinu. Výlučne mad’arčinu používajú štyria (13\%). Dvojjazyčne komunikujú tiež štyria (13\%), 7 \% (2) obyčajne po slovensky a takisto $7 \%$ (2) obyčajne po mad'arsky. Je vel'mi pravdepodobné, že tí, ktorí v obchode komunikujú vždy po slovensky, žijú v menších obciach, kde je slovenčina ešte živá, obyvatelia sa navzájom poznajú, vedia kto má aký pôvod a v akom jazyku sa môžu rozprávat'.

„U nás v obchode nikto nevie po slovensky, takže ani keby som chcel, nevedel by som komunikovat' po slovensky. " (respondent)

Pri otázke o probléme dohovorit' sa s domácim lekárom po slovensky $17 \%$ (5) neodpovedalo, $20 \%$ (6) malo $\mathrm{v}$ danej situácii problém, lebo lekár neovládal slovenčinu. Prekvapujúce však bolo, že $63 \%$ (19) nemalo problém dohovorit' sa s lekárom po slovensky. Pravdepodobne ide o rovnaký dôvod, ako v prípade nákupu v obchode.

Vzájomnú komunikáciu respondentov pri vzájomnom stretnutí sa mimo domáceho prostredia alebo školy vždy po slovensky deklaroval iba jeden. Dvaja (7 \%) používajú obyčajne slovenčinu, traja (10 \%) obyčajne mad'arčinu. Štyria študenti (14 \%) sa 
údajne vôbec s ostatnými spolužiakmi nerozprávajú. $33 \%$ (10) komunikuje dvojjazyčne a rovnaká čast' používa vždy mad'arčinu.

Tretina skúmaných študentov sa vôbec nezúčastňuje na aktivitách slovenských organizácií. Z tých, čo sa zúčastňujú, jeden používa vždy mad’arčinu, dvaja vždy slovenčinu, štyria obyčajne mad'arčinu, štyria obyčajne slovenčinu. Najviac zúčastnených $(30 \% / 9)$ používa obidva jazyky paralelne.

Z výskumu vyplýva, že v komunikácii študentov so všetkými rodinnými príslušníkmi najčastejšie dominuje mad'arčina. Používanie slovenského jazyka, resp. oboch jazykov paralelne je pre nich najprirodzenejšie a najl'ahšie v komunikácii v rámci lokálnej society - na obecnom úrade (ak majú slovensky hovoriacich zamestnancov), $\mathrm{v}$ obchode $\mathrm{s}$ predavačom, no aj pri vzájomnom stretnutí sa $\mathrm{v}$ cudzom meste a na aktivitách slovenských organizácií. Všeobecne rozšírená téza o pozitívnom vplyve rodinného prostredia na znalost' a používanie minoritného jazyka tu už neplatí.

Je potrebné upozornit' na to, že používanie obidvoch jazykov v uvedených komunikačných situáciách má charakter jazykovej bipolarity študentov - paralelné používanie slovenčiny a mad’arčiny. Striedavé dvojjazyčné používanie jazykov je častejšie $\mathrm{v}$ komunikácii $\mathrm{s}$ učitel'mi slovenčiny ako $\mathrm{v}$ rodinnom prostredí $\mathrm{v}$ komunikácii so starými rodičmi $\mathrm{z}$ matkinej strany. Pomerne vysoké percento študentov sa rozpráva obyčajne po slovensky s priatel'mi a známymi Slovákmi a s učitel'mi slovenčiny. Naopak, obyčajne po slovensky komunikujú s matkou len $3 \%$ (1), s otcom $0 \%$, so starými rodičmi z matkinej strany $10 \%$ (3), so starými rodičmi z otcovej strany $0 \%$, so súrodencami $0 \%$, s kňazom $0 \%$, s členmi cirkevného zboru 3 $\%$ (1), so susedmi $0 \%$ a s priatel'mi a známymi Slovákmi, ak je v komunikácii prítomný aj Mad'ar, $10 \%$ (3).

Všetci respondenti bez výnimky sa vo všeobecnosti považujú za dvojjazyčných a to i napriek tomu, že oba jazyky neovládajú na rovnakej úrovni. Dvojjazyčnost' je v prostredí Slovákov v Mad’arsku asymetrická, na úkor slovenčiny. (Uhrinová, 2011b: 87; Tóth - Tušková - Uhrinová - Žiláková, 2005: 272-275; Homišinová - Uhrinová - Ondrejovič, 2013: 51; Tušková, 2012: 113-121) Dokazuje to aj predmetný výskum. Jestvovanie slovenského jazyka v Mad'arsku je ambivalentné - jeho vývin aj ústup sa dejú paralelne. (Uhrinová, 2008: 93) Rozvoj je evidentný v spoločenskej/inštitucionálnej sfére slovenskej inteligencie v Mad'arsku, regres v súkromnej, rodinnej sfére a v prostredí cirkvi.

„Páči sa mi to, ked’ sa viacerí so slovenskými koreňmi stretneme, alebo aj so staršími a viem sa pozhovárat' po slovensky. Po štúdiu môžem pracovat' ako učitel' slovenčiny na slovenskej škole. " (respondent)

„Po škole by som chcel ist' na doktorantúru a venovat' sa tomu, lebo ma to baví. Slovenský jazyk, literatúra, alebo aj národnostné prostredie. " (respondent)

\section{Osobná rovina}

Sociálno-psychologická podstata použivania jazyka sa u jednotlivcov prejavuje nielen smerom von (kolektívne), ale aj dovnútra (individuálne). Vnútorný, imanentný jazyk je jazyková forma, v ktorej sú konštruované obsahy vnútornej reči. Formálne je úplná, no ostáva neexplikovaná, nevypovedaná do okolia, pričom nemusí korešpondovat's jazykovým kódom vypovedanej podoby. To znamená, že človek vo svojej mysli skonštruuje obsahy $\mathrm{v}$ jednom jazyku, no vyjadrit' ich môže v inom jazyku. Preto okruh skúmaných komunikačných situácií tvorili aj nasledovné témy: V ktorom jazyku sa vám sníva, individuálne sa modlíte, rátate peniaze, hrešíte?

Z frekvenčnej analýzy odpovedí vyplynulo, že výlučne mad'arčinu používa 14 (47 \%) pri snívaní, 12 (40 \%) modlení, 20 (67 \%) rátaní peňazí, 10 (33\%) hrešení. Nikto ani raz nevybral odpoved' vždy po slovensky. Obyčajne v slovenčine udal - 1 (3\%) snívanie, $2(7 \%)$ rátanie peňazí, modlenie a hrešenie. Obyčajne mad’arčinu

XLinguae, Volume 14 Issue 2, April 2021, ISSN 1337-8384, eISSN 2453-711X 
deklarovalo 6 (20\%) pri snívaní, 5 (17 \%) pri hrešení, 4 (13\%) pri modlení a 3 (10 $\%)$ pri rátaní peňazí. Obidva jazyky používajú 4 (13\%) pri rátaní peňazí, 7 (23\%) pri hrešení, 4 (14 \%) pri snívaní. Nikto nevybral odpoved’ že pri modlitbe používa obidva jazyky. 12 (40 \%) sa nemodlia, 1 (3 \%) zadal, že sa mu nesníva a 4 (13\%) že vôbec hrešia.

Z uvedených výsledkov je zrejmé, že imanentným jazykom respondentov je mad'arčina, slovenčina ustupuje do úzadia. Podl'a Skutnabb-Kangasovej jazyk, v ktorom človek počíta, rozmýšla, píše si denník alebo básne, resp. v ktorom sa mu sníva, hovorí viac o jeho osobnosti ako o jeho materinskom jazyku. (2000: 34) Imanentný jazyk je vo svetle aktuálnych výskumov možné rozšit' aj o problematiku vnímania obklopujúceho životného priestoru a krajiny prostredníctvom mentálnych máp a pomenovaní v minoritnom jazyku, nezriedka prevzatými aj majoritou. (Chrastina - Župčán - Tuska - Hlásznik 2019, Chrastina- Hronček - Gregorová Žoncová 2020)

I napriek výraznej dominancii mad’arského jazyka je zhl'adiska používania slovenčiny $\mathrm{v}$ prostredí skúmanej skupiny ako budúcej národnostnej inteligencie pozoruhodné, že tretina respondentov na aktivitách slovenských organizácií komunikuje dvojjazyčne (aj v slovenčine) a rovnaká čast' pri vzájomnom stretnutí sa v cudzom meste.

Respondenti si uvedomujú význam zachovávania slovenčiny v kontexte udržiavania minoritnej identity. Z vlastnej skúsenosti potvrdzujú, že podstatným predpokladom je formálne národnostné vzdelávanie s následným komunikačným sociálnym prostredím ako priestoru jeho používania a zdokonal'ovania:

„,Deti už v škôlke by sa mali oboznamovat' so slovenským jazykom, aby pozdejšie im bolo bližši jazyk, aby to radšej sa učili."

„Treba deti naucit' po slovensky."

„,Treba lepšie podporovat' národnostné škôlky, školy a organizovat' viac slovenské podujatie."

„Pokračovat'v učení slovenského jazyka.,

„Zničit' negativne stereotipiá, použivat' slovenský jazyk na rôznych doménoch, byt' vzorom pre det'mi, hovorit' po slovensky s det'mi, motivovat' ich viac.'

„,Musíme založit' kolektívy kde môžeme rozprávat's a po slovensky."

„Viac by mali vážit' učitel'ov."

„Spojenie je potrebné. Tradície musíme odovzdat', školy mali by mat' väčšiu úlohu."

„Malé deti naučit' po slovensky, zachovat' kultúru a slovenské spolky."

„Treba podporovat' lepšie školstvo."

\section{Dodatok: uvádzanie mena a priezviska ako etnoidentifikačná situácia}

Zistené výsledky vyvolávajú otázku, či mená v dotazníkoch uvedené v slovenskej podobe skutočne nejako súvisia s pocit’ovanou etnicitou (a demonštrujú národnostnú príslušnost'), alebo ide o zautomatizovaný návyk uplatňujúci sa v prípade práce $\mathrm{s}$ textom v slovenčine.

Používanie slovenskej podoby ženských priezvisk (so sufixom -ová) totiž nemá v Mad'arsku dlhú tradíciu. Ofíciálne sa môže uplatňovat' od roku 1949, kedy sa tu založili slovenské národnostné školy. Vo verejnej sfére sa to udomácnilo až po roku 1970 v rámci znovuoživovania slovenskej národnostnej kultúrnej a spolkovej činnost'. Dovtedy sa aj v matrikách evanjelickej cirkvi (napríklad v Békešskej Čabe od roku 1728), aj katolíckej cirkvi (napríklad v Békešskej Čabe od roku 1750) uvádzali neprechyl'ované podoby priezvisk, lebo sa zapisovali najprv do latinských matrík predovšetkým $\mathrm{v}$ bibličtine gotickým písmom a od roku 1836 po prijatí zákona o mad'arskom jazyku podl'a noriem mad'arského pravopisu. (Tušková - Uhrinová, 2016) Z diskusií s respondentmi, už mimo realizácie dotazníka, vyplynulo, že väčšina z nich uvádza vlastné meno a priezvisko na slovenských dokumentoch automaticky 
v slovenčine ako návyk vytvorený počas stredoškolského štúdia na slovenskej národnostnej škole. ,,Ked' je slovenský text, automaticky sa podpíšem po slovensky. Už zo zvyku sa podpisujem po slovensky. " (respondent)

Jeden študent svoje meno uvádza po slovensky ako demonštráciu svojej národnostnej príslušnosti. ,Som na to citlivý. Vytvorilo sa to u mйa v (slovenskom - pozn. aut.) gymnáziu. Dokonca namiesto -ny použivam vo svojom mene -n s mäkčeňom, teda -n̆. Pokladám sa za Slováka. "(respondent)

Vplyv národnostného vzdelávania je evidentný z výsledkov parciálneho výskumu realizovaného s ciel'om identifikovat' a vysvetlit' používanie slovenskej alebo mad'arskej podoby vlastného mena a priezviska (Tušková - Uhrinová 2016):

„Na slovenskom gymnáziu som použivala podobu Kuštárová. Prelínanie podôb Kustár/Kustárová/Kuštárová bolo charakteristické od študentských čias na Slovensku. Použivanie neni dôsledné doteraz, ale preferujem formu Kustár. Formu Kustárová často vyslovili aj so s, písat'so š ako Kuštárová je mi cudzie." (žena, 46 r.)

„Zato použivam mad’arskú podobu, lebo v rodnom liste je mi tak uvedenô meno. V mojom detstve aj pani učitel'ky aj žiaci použivali koncovku -ová. Po 1990 rokoch použivame priezvisko bez -ová." (žena 48 r.)

„Lebo jedna profesorka mi to povedala, že ked'som sa narodila dostala som toto meno." (žena 41)

Používanie mad’arskej formy priezviska občanmi Mad'arska slovenského pôvodu odôvodňujú odpovede typu:

„Pretože to je moje oficiálne meno a priezvisko.” (žena 42r.)

„Som občanom Mad'. rep. v občanskom preukaze som takto napísaná."(žena 44 r.)

„Použivam priezvisko tak, ako ho mám v občianskom preukaze a vo všetkých úradných papieroch." (žena $63 \mathrm{r}$.)

„Lebo vlastne, to je moje meno, takto mám to vo všetkých dokumentoch. To pre mn̆a až tak nesúvisi s identitou. Jednoduchšie je použivat' oficiálne meno, lebo potom nemôžem mat'žiadne problémy. Medzi Slovákmi nie je zlé, ked’oni hned'vedia že nie som Slovákom (zo Slovenska) lebo potom odpustia mi jazykové chyby. Ja som nemala žiadne problémy, ale môže sa stat', ked' niekto má vel'mi odlišné meno, že niektorí nevedia, že to je tá istá osoba... Podl'a mn̆a, znelo by čudne, keby slovenski aktivisti použivali by mad'arské mená. Aj ja som sa zúčastnila v mnohých slovenských programoch, možno preto, niekedy moji kamaráti ma nazývali Hornoková medzi sebou... V poslednom čase ale skúsim viac zdôrazňovat' moje slovenské korene, preto niekedy použivam moje meno $s$-ová, napr. v email adresach. Ked' som chodila na strednú školu, niektori učitelia vždy použivali naše priezviská s-ová. Pre niektorých to bolo naozaj vzrušujúce, lebo pokladali svoje meno za vel'mi súkromnú záležitost' a nevedeli sa stým stotožňovat'. Niektori iní (učitelia zo Slovenska) zásadne nepouživali naše priezviská s-ová. Moje meno ani na Slovensku na univerzite nikdy nikto nepoužival s-ová, ani v dokumentoch, ani slovne.” (žena 27 r.)

\section{Záver}

Výskum prináša poznatky o tom, aký jazyk si vysokoškoláci slovenského pôvodu v Mad'arsku študujúci slovakistiku sperspektívou profesionálne pôsobit' v národnostnom živote Slovákov v Mad’arsku vyberajú v rôznych komunikačných situáciách. Analýza potvrdila hypotézu, že skúmaná skupina respondentov vo všetkých komunikačných sférach a komunikačných situáciách preferuje mad’arský jazyk (avšak vo viacerých situáciách s kritickou poznámkou, že v určitých komunikačných sférach objektívne neexistuje reálna možnost' použitia slovenského jazyka). Rovnako ani zostupná tendencia používania slovenského a absolútna dominancia mad'arského jazyka neprekvapila. Mad'arský spisovný jazyk príslušníci slovenských komunít v Mad’arsku vždy považovali za absolútnu normu. (Žiláková, 2004c: 123) Aj výsledky d’alších výskumov potvrdzujú výrazne klesajúcu tendenciu

XLinguae, Volume 14 Issue 2, April 2021, ISSN 1337-8384, eISSN 2453-711X 
používania slovenského jazyka. (Divičanová, 1999c: 335, 2002a: 533; Žiláková, 2004c: 119-131) Bez ohl’adu na to, rešpekt a podpora národnostných vzdelávacích, kultúrno-spoločenských a rekreačno-oddychových aktivít a angažovanosti mladých príslušníkov komunít sú pre etnokultúrnu aj etnojazykovú kontinuitu existenčne dôležité bez ohl'adu na jazyk. Minoritný jazyk aj v prostredí Slovákov v Mad'arsku síce je dôležitým etnoidentifikačným faktorom, ale nie jediným. Tak, ako jeho nahradenie majoritným neznamená automaticky zánik minority, ani jeho pretrvanie automaticky nezabezpečuje prežitie minority. Etnolingvistické výskumy poznajú množstvo prípadov, kedy minorita i nad’alej jestvuje i ked' ako jazykovo asimilovaná. V problematike záujmu, štúdia a používania minoritného jazyka v prostredí detí a mládeže slovenského pôvodu v Mad'arsku je potrebné i nad'alej využívat' aktuálne možnosti národnostného vzdelávania. Ked’že v Mad'arsku sa slovenčina používa len pri komunikácii $\mathrm{v}$ menšinovom prostredí, navyše, v redukovaných situáciách, príležitostiach, v rámci užívatel'ov najmä najstaršej a z časti strednej generácie, problematika udržiavania menšinového jazyka sa tu čoraz viac prelína s problematikou jazykovej revitalizácie - nielen vedomého, sofistikovaného a inštitucionálneho udržiavania jazyka, ale aj vedomého, sofistikovaného a inštitucionálneho znovuoživovania tam, kde je to relevantné a kde je o to záujem. ${ }^{13}$ Využívanie výsledkov vedeckých výskumov v národnostnej praxi je v Mad'arsku podmienené politickou vôlou/aktuálnou situáciou aj manažmentom a prístupom Celoštátnej slovenskej samosprávy ako vrcholného orgánu Slovákov v Mad’arsku. Samospráva sa v rámci svojich možností snaží vytvárat' také podmienky, aby sa v predmetnom výskume skúmaní študenti ani po skončení štúdia nevzdialili od slovenskej minority, aby nad'alej zostali $\mathrm{v}$ kontakte $\mathrm{s}$ menšinovou komunitou a pôsobili v nej. Najdôležitejšiu úlohu tu nakoniec zohráva ich vlastná motivácia. Elity smerom „dovnútra“ sú vzormi pre ostatných členov minority a smerom „von“ sú reprezentantmi celej minority. Ony vytvárajú z najväčšej miery celkový obraz minority. Inak by to neboli elity.

\section{Bibliographic references}

BALLEKOVA, K. 2003. Z narecovych vyskumov Slovakov v Madarsku. In: Slovencina $\mathrm{v}$ mensinovom prostredi. Materialy z medzinarodnej vedeckej konferencie Vyskumneho ustavu Slovakov v Madarsku. 16. - 17. oktobra 2003. Bekesska Caba: VUSM. ISBN $963-$ 8657-324

BALLEKOVA, K. 2006. Prezentovanie slovenskych nareci z Madarska. In: Kultura, jazyk a historia Slovakov $\mathrm{v}$ Madarsku. Materialy $\mathrm{z}$ jubilejnej interdisciplinarnej medzinarodnej vedeckej konferencie z prilezitosti 15. vyrocia zalozenia Vyskumneho ustavu Slovakov v Madarsku. Bekesska Caba: VUSM. ISBN 9638657383

BLANAR, V. 1950. Prispevok ku studiu slovenskych osobnych a povestnych mien v Madarsku. Bratislava: Slovenska akademia vied a umeni.

BORYS, D. - GARMASH, O. 2019. English Religious Slang in Search of Linguistic Identity. In: European Journal of Science and Theology, vol 15, n. 5, pp. 49-66.

BOSAK, J. 1995. Sociolingvisticka strategia vyskumu slovenciny. In: Sociolinguistica Slovaca 1. Sociolingvisticke aspekty vyskumu sucasnej slovenciny. Bratislava: Veda. ISBN 80-224-0160-9

CSASZARI, E. 2011. Bukkszentkereszt - egy magyarorszagi szlovak kozseg - lakosainak ketnyelvüsege es a benne rogzult vilag, nyelvi kepe. Budapest: ELTE. Doktori ertekezes. Kezirat.

DANEK, J. 2019. Value Orientation in the Proceses of the World's Global Direction and Its Problems. In: Ad Alta - Journal of Interdisciplinary Research, vol. 9, n. 2, pp. 22-24.

\footnotetext{
${ }^{13}$ K problematike revitalizácie v prostredí etnických minorít bližšie Slobodová Nováková Koštialová - Kušnierová - Kurajda, 2018, Darulová - Koštialová - Slobodová Nováková, 2018.
} 
DARUlova, J. - KOSTIALOVA, K. - SlOBODOVA NOVAKOVA, K. 2018. Cultural and Confesional Specifics of National Minorities of Slovakia as a Part of Identity examplex of Urban and Rural Enviroment. In: European Journal of Science and Theology, vol 14, n. 6, pp. 107-114.

DIVICANOVA, A. 1999a. Hodnota nareci a ich konfrontacia s nenarecovymi jazykovymi vrstvami na slovenskych jazykovych ostrovoch v Madarsku. In: Narecia a narodny jazyk. Bratislava: Veda. ISBN 8022405957

DIVICANOVA, A. 1999b. Stracanie hodnot materinskeho jazyka u Slovakov v Madarsku. In: Odborne zdruzenie ucitelov slovenciny v Madarsku. Segedin: Segedinska slovenska mensinova samosprava - Celostatna slovenska samosprava .

DIVICANOVA, A. 1999c. Jazyk, kultura, spolocenstvo. Etnokulturne zmeny na jazykovych ostrovoch v Madarsku. Bekesska Caba - Budapest: Slovensky vyskumny ustav Zvazu Slovakov v Madarsku. ISBN 963-0369-133

DIVICANOVA, A. 2001b. A nyelvjarasok es nem nyelvjarasi retegek ertekrendszere. In: Hungaro-Slavica 2001. Studia in honorem Iani Banczerowski. Budapest: ELTE, Szlav es Balti Filologiai Intezet.

DIVICANOVA A. 2002a. Dimenzie narodnostneho bytia a kultury. Bekesska Caba: VUSM. ISBN 963-2060-571

DIVICANOVA, A. 2004. Ambivalentne hodnoty slovenskeho jazyka v Madarsku v stredoeuropskom kontexte. In: Slovencina $\mathrm{v}$ mensinovom prostredi. Bekesska Caba: VUSM. ISBN 963-8657-324

DOLNIK, J. 2010. Teoria spisovneho jazyka (so zretelom na spisovnu slovencinu). Bratislava: Veda. ISBN 978-80-224-1119-6

FUGEDI, E.- GREGOR, F. - KIRALY, P. 1993. Atlas slovenskych nareci v Madarsku Atlas der slowakischen Mundarten in Ungarn. Budapest: Slovensky ustav Zvazu Slovakov v Madarsku. ISBN 963-0432-803

GREGOR, F. 1998. A csabai szlovakok nyelve. In: A müvelodes evszazadai Bekescsaban. Bekescsaba: Bekescsaba Megyei Jogu Varos. ISBN 9789630343480

HOMISINOVA, M. 2003. Slovenska inteligencia v Madarsku v zrkadle sociologickeho vyskumu. Bekesska Caba: VUSM. ISBN 1335-3608

HOMISINOVA, M. 2006. Etnicka rodina Slovakov, Chorvatov a Bulharov zijucich v Madarsku. Bekesska Caba: VUSM. ISBN 963-8657375

HOMISINOVA, M. - UHRINOVA, A. - ONDREJOVIC, S. 2013. Poslanci slovenskych narodnostnych samosprav v Madarsku v reflexii sociolingvistickeho vyskumu. Bekesska Caba: VU CSSM. 9786155330001

HORNOK, R. 2020. "We are Slovaks too, just not in that way" The Experience of The Slovak Minority Youth From Hungary Studying in The Kin-State. In: Človek a spoločnost' [Individual and Society], vol. 23, n. 4, pp. 57-73.

HORNOKNE UHRIN, E. 2000. A bekescsabai szlovak ertelmiseg anyanyelvhasznalata. Budapest - Bekescsaba. Doktori ertekezes. Kezirat. ISBN 0489002864160

CHRASTINA, P. - HRONCEK, P. - GREGOROVA, B. - ZONCOVA, M. 2020. LandUse Changes of Historical Rural Landscape-Heritage, Protection, and Sustainable Ecotourism: Case Study of Slovak Exclave Civ (Piliscsev) in Komarom-Esztergom County (Hungary). In: Sustainability, vol. 12, n. 15, pp. 1-25.

CHRASTINA, P. - TROJAN, J. - ZUPCAN, L. - TUSKA, T. - HLASZNIK P. P. 2019. Land Use as a Means of the Landscape Reoitalization: An Example of the Slovak Exclave of Tardos (Hungary) | Land use ako nastroj reoitalizacie krajiny: na priklade slovenskej exklavy Tardos (Madarsko). In: Geographia Cassoviensis, vol. 13, n. 2, pp. 121-140.

IVANISHCHEVA, O. N. 2016. Dictionaries of Critically Endangered Languages: Focus on Users. In: Jazykovedny casopis, vol. 67, n. 1, pp. 73-86.

LALINSKA, M. - STRANOVSKA, E. - GADUSOVA, Z. 2020. Measurement of Reading Comprehension in Second Foreign Language. In: 14th International Technology,

XLinguae, Volume 14 Issue 2, April 2021, ISSN 1337-8384, eISSN 2453-711X 
Education and Development Conference (INTED2020), Book Series: INTED Proceedings, pp. 5018-5026.

LANSTYAK, I. 1996. K niektorym otazkam madarsko-slovenskeho bilingvizmu. In: Sociolinguistica Slovaca 2. Sociolingvistika a arealova lingvistika. Bratislava: Veda. ISBN 80-224-0479-9

LANSTYAK, I. 2002. Madarcina na Slovensku - studia z variacnej sociolingvistiky. In: Sociologicky casopis, vol. 38, n. 4, pp. $409-427$.

LANSTYAK, I. 2005. Striedanie kodov v kontexte asymetrickeho bilingvizmu. In: Jazyk a komunikacia v suvislostiach. Bratislava: Univerzita Komenskeho. ISBN 80-223-2023-4 LANSTYAK, I. - SZABOMIHALY, G. 1997. Magyar nyelvhasznalat - iskola ketnyelvüseg. Pozsony: Kalligram. ISBN 80-7149-173-X

LENOVSKY, L. 2008. Studenti z prostredia etnickych minorit na UKF v Nitre v kontexte zachovavania identity a slovenciny ako mensinoveho jazyka. In: Slovencina v mensinovom prostredi: studie z II. medzinarodnej vedeckej konferencie Vyskumneho ustavu Slovakov v Madarsku. Bekesska Caba: VUSM. ISBN 978-963-87342-5-9

LESFALVINE CSENGODI, A. 2010. A szlovak jogi es politikai terminologia fejlodese a XIX. sz. masodik feletol. Budapest. Doktori ertekezes. Kezirat.

MURIN, I. 2016. Generational Transsmition in Local Culture An Exploration of European Research Drivers in Central Slovakia. In: Anthropological Journal of European Cultures, vol. 25, n. 2, pp. 57-72.

NOBIKOVA, A. 2011. Sprava o celokrajinskej slovenskej sluzbe. In: Cirkevna kultura Slovakov v Madarsku. Bekesska Caba: VUSM. ISBN 978-963-88583-4-4

ONDREJOVIC, S. 2008. Jazyk, veda o jazyku, societa: sociolingvisticke etudy. Bratislava: Veda. ISBN 978-80-224-0994-0

ONDRUS, P. 1956. Stredoslovenske narecie v Madarskej republike. Bratislava: Vydavatelstvo SAV.

SIROTOVA, M. - MICHVOCIKOVA, V. 2016. Multicultural Society from View of University Student. In: Journal of Language and Cultural Education, vol. 4, n. 3, pp.3245.

SIROTOVA, M. - MICHVOCIKOVA, V. 2019. The Importance of Supervised Practice Teaching in University Study of University Students - Future Teachers of Slovak and Foreign Languages $=$ Vyznam pedagogickej praxe $\mathrm{v}$ pregradualnej priprave ucitelov slovenskeho jazyka a cudzich jazykov. In: XLinguae : European Scientific Language Journal, vol. 12, n. 3, pp. 228-239.

SKUTNABB-KANGAS, T. 1991. Bilingvizam da ili ne. Beograd: Zavod za udzbenike i nastavna sredstva. ISBN 8617015330

SKUTNABB-KANGAS, T. 2000. Mensina, jazyk a rasizmus. Bratislava: Kalligram. ISBN 8071493511

SLOBODOVA NOVAKOVA, K. - KOSTIALOVA, K. - KUSNIEROVA, D. KURAJDA, L. 2018. Minority Languages in Europe in the Context of Revitalizing Activities (Mensinove jazyky v Europe v kontexte revitalizacnych aktivit). In: XLinguae, vol. 11, n. 3, pp. 16-27.

SZABONE, M. J. 2012. A pilisi szlovak falvak nyelvi sajatossagai. Budapest: ELTE . Doktori ertekezes. Kezirat.

SZABOOVA, O. 2004. Problem dvojjazycnosti a dvojitej identity Slovakov v Madarsku v zrkadle statistickych udajov. In: Slovencina v mensinovom prostredi. Bekesska Caba: VUSM. ISBN 963-8657-324

STEFANIK, J. 2004a. Cinitele urcujuce jazykovu uroven bilingvalnych skol. In: Slovencina v mensinovom prostredi. Bekesska Caba: VUSM. ISBN 96-3865-732-4.

STEFANIK, J. 2004b. Vedia alebo nevedia? K otazke ovladania dvoch jazykov na juznom Slovensku. In: Studia Academica Slovaca 33. Prednasky XL. letnej skoly slovenskeho jazyka a kultury. Bratislava: Stimul - Centrum informatiky a vzdelavania FF UK. ISBN 80-8898-282-0 
STOLC, J. 1949. Narecie troch slovenskych ostrovov v Madarsku. Bratislava: Slovenska akademia vied a umeni.

TELEKESOVA-VAMOSOVA, E. 2004. Niektore sociolingvisticke aspekty madarskoslovenskej dvojjazycnosti ziakov zakladnych skol v Madarsku. In: Slovencina v mensinovom prostredi. Bekesska Caba: VUSM. ISBN 963-8657-324

TOTH, J. A. - TUSKOVA, T. - UHRINOVA, A. - ZILAKOVA, M. 2005. Jazykova situacia v Slovenskom Komlosi. In: Pouzivanie slovenskeho jazyka v Bekesskej zupe. Bekesska Caba: VUSM. ISBN 9638657332

TUSKA, T. 2002. A „Cabiansky kalendar“ 1920 - 1939 evfolyamaiban megjelent cikkek nyelvszemlelete. Budapest - Bekescsaba. Doktori ertekezes. Kezirat.

TUSKOVA, T. 2001. Niektore zvlastnosti jazyka Cabianskeho kalendara. In: Narodopis Slovakov v Madarsku 17. Budapest: Madarska narodopisna spolocnost.

TUSKOVA, T. 2007-2008. Vztah medzi spisovnou slovencinou a cabianskym narecim v hlaskoslovnej rovine $\mathrm{v}$ zrkadle Cabianskeho kalendara. Konsonanty. In: Slavica Szegediensia VI. Szeged: Felsooktatasi Kiado.

TUSKOVA, T. 2012. Akym jazykom, s kym a kedy rozpravaju nasi mladi v Madarsku. In: Individualna in kolektivna dvojezicnost. Ljubljana: Filozofska Fakulteta. ISBN 978961-237-557-7

TUSKOVA, T. - UHRINOVA, A. 2016. Sonda do problematiky pouzivania priezvisk Sloveniek v Madarsku v sucasnosti. In: Jazykovedne studie XXXIII. Prechylovanie: ano nie? Bratislava: Veda . ISBN 978-80-224-1550-7

UHRINOVA, A. 2008. Slovensky jazyk v Madarsku ocami pouzivatelov. In: Slovensky jazyk v Madarsku I. Bekesska Caba: VUSM. ISBN 978-963-87342-4-2

TUSKOVA, T. - UHRINOVA, A. 2018. „Skola by sa len vtedy zachranila...“ (Pribeh slovenskej narodnostnej skoly v Tardosi). In: Slovenske inspiracie z Tardosa. Studia interdisciplinaria. Bekesska Caba: VUSM. ISBN 978-615-5330-15-5

UHRINOVA, A. 2011b. Z vysledkov sociolingvistickeho vyskumu Slovensky jazyk v Madarsku. In: Sucasna slovenska jazykova situacia v Madarsku. Nadlak: Vydavatelstvo Ivan Krasko. ISBN 9789731070742

UHRINOVA, A. 2015. K jazykovym autobiografiam jubilanta a Venarcanov. In: Duchovna a socialna kultura mensin $\mathrm{v}$ majoritnom prostredi. Zbornik z medzinarodnej vedeckej konferencie venovanej zivotnemu jubileu etnografa Ondreja Krupu. Bekesska Caba: VUSM. ISBN 978-615-5330-04-9

ZSILAK, M. 1991. A magyarorszagi szlovakok nyelvallapotarol es ketnyelvüsegerol. In: Ketnyelvüseg a Karpatmedenceben I. Budapest: Szechenyi Tarsasag. ISBN 9637557016 ZSILAK, M. 1992. Identitastudat - nyelvatorokites. In: Ketnyelvüseg a Karpatmedenceben II. Budapest : Szechenyi Tarsasag. ISBN 963-7557-05-9

ZSILAK, M. 1993. A delalfoldi szlovak nyelvjarasok funkcionalis retegzodese. In: Hungarologia 3. Budapest: Nemzetkozi Hungarologiai Kozpont. ISSN 1217-4343

ZSILAK, M. 1996. A totkomlosi szlovak nyelv funkcionalis retegzodese. In: Totkomlos neprajza. Totkomlos: Totkomlos varos onkormanyzata. ISBN 0739000533163

ZILAKOVA, M. 1986. Narecie troch slovenskych obci v Bakoni s osobitnym zretelom na pozostatky aoristu. Budapest: Tankonyvkiado. ISBN 9631786277

ZILAKOVA, M. 2004a. Slovencina v Madarsku na zaciatku 21. storocia. In: Slovencina v mensinovom prostredi. Bekesska Caba: VUSM. ISBN 963-8657-324

ZILAKOVA, M. 2004b. Dynamika jazyka Slovakov v Madarsku. Opera Slavica Budapestinensia. Linguae Slavica. Budapest: ELTE BTK. ISSN 1785-9816

ZILAKOVA, M. 2004c. Jazykovy obraz sveta (the linguistic image of the world) Slovakov v Madarsku v kontexte bilingvizmu. In: Dynamika jazyka Slovakov v Madarsku. Opera Slavica Budapestinensia. Linguae Slavicae. Budapest: ELTE BTK. ISSN 1785-9816

XLinguae, Volume 14 Issue 2, April 2021, ISSN 1337-8384, eISSN 2453-711X 
ZILAKOVA, M. 2005. Premeny nestandardizovanych a standardizovanych podob slovenskeho jazyka v Bekesskej zupe. In: Pouzivanie slovenskeho jazyka v Bekesskej zupe. Bekesska Caba: VUSM. ISBN 9638657332

ZILAKOVA, M. 2008a. Odumieranie nareci na slovenskych jazykovych ostrovoch v Madarsku. In: Slovensky jazyk v Madarsku. Bibliografia a studie I. Bekesska Caba: VUSM. ISBN 978-9638-734-242

ZILAKOVA, M. 2008b. Narodopis Slovakov v Madarsku (1975 - 2007). Jazykova analyza. In: Slovensky jazyk v Madarsku. Bibliografia a studie II. Bekesska Caba: VUSM. ISBN 978-9638-734-242

ZILAKOVA, M. 2008c. Dve stranky jednej mince. In: Slovensky jazyk v Madarsku. Bibliografia a studie II. Bekesska Caba: VUSM. ISBN 978-9638-734-242

Words: 8767

Characters: 63231 (35,13 standard pages)

prof. PhDr. Ladislav Lenovský, PhD.

St. Cyril and Methodius University in Trnava

Faculty of Arts

Nám. J. Herdu 2

91701 Trnava,

Slovakia

ladislav.lenovsky@ucm.sk

doc. PaedDr. Tünde Tušková, PhD.

University of Szeged Gyula Juhász

Faculty of Education

Boldogasszony sgt. 6.

6725 Szeged,

Hungary

tuska.tunde@szte.hu 